\title{
Motivasi Kerja Karyawan Pada PT. Dwie Karya Ghom (Golden Hill Oil Mill) Desa Sei Hanyo Kecamatan Kapuas Hulu Kabupaten Kapuas
}

\author{
W. Agustiana, Tonich, R. Alexandro \\ Program Studi Pendidikan Ekonomi \\ Fakultas Keguruan dan Ilmu Pendidikan \\ Universitas Palangka Raya \\ Kampus UPR Tunjung Nyaho Jalan Hendrik, Indonesia
}

(Diterima 20-10-2019; Disetujui 26-11-2019)

\begin{abstract}
ABSTRAK
Penelitian ini dilatar belakangi oleh motivasi kerja karyawan karena untuk mewujudkan tujuan perusahaan tidaklah mudah diperlukan sumber daya manusia yang profesional, manajemen yang baik dan organisasi yang sehat. Berdasarkan hasil penelitian diketahui bahwa Motivasi instrinsik karyawan perusahaan bisa dikatakan sudah cukup baik karena sebagian besar karyawan PT. Dwie Warna Karya GHOM (Golden Hill Oil Mill) Desa Sei Hanyo Kecamatan Kapuas Hulu Kabupaten Kapuas sudah memperoleh keberhasilan dalam mencapai sesuatu dan sebagian besar dari mereka memperoleh pengakuan dari atasan mereka, dan sifat pekerjaan yang dilakukan sudah sesuai dengan standar pekerjaan dan mereka mempunyai rasa tanggung jawab yang baik terhadap pekerjaan yang mereka jalani. Motivasi ekstrinsik karyawan perusahaan bisa dikatakan kurang baik dikarenakan jawaban dari masing-masing narasumber atau karyawan banyak yang mengeluh.

Yang pertama terhadap kebijakan organisasi perusahaan yang masih tidak jelas dan tidak tetap sewaktu-waktu bisa mengalami perubahan dan tidak ada ketegasan terhadap peraturan yang diberlakukan, yang kedua terhadap pelaksanaan kebijakan organisasinya juga tidak jelas karena dari kebijakannya yang tidak tetap selalu berubah-ubah membuat pelaksanaannya pun tidak baik, yang ketiga terhadap hubungan interpersonal tidak ada permasalahan dalam hubungan antar sesame rekan kerja karyawan memiliki hubungan kerja yang baik, yang keempat terhadap kondisi kerja disini karyawan itu sendiri banyak mengeluh terutama terhadap perlengkapan kerja contohnya seperti pemberian APD (alat perlindungan diri) padahal setiap 6 bulan sekali ada anggaran untuk hal itu. Begitu juga terhadap alat-alat penunjang kerja yang sangat masih kurang, dan yang keenam sistem upah dan gaji dalam pelaksanaan penggajian masih tidak tepat waktu dikarenakan pada saat closing dari pihak estate selalu terlambat untuk closing payroll, maka dari itu pihak pabrik juga akan menerima gaji pun terlambat.
\end{abstract}

Kata Kunci: Motivasi Instrinsik dan Ekstrinsik

\section{PENDAHULUAN}

Perusahaan pada saat ini sering menghadapi berbagai persaingan di dalam dunia bisnis yang semakin maju. Oleh karena itu perusahaan harus dibangun dengan sungguh-sungguh agar dapat menghasilkan karyawan yang berkualitas sehingga mampu bersaing dengan perusahaan lain. Dalam suatu perusahaan karyawan merupakan asset utama perusahaan yang paling berharga, maju mundurnya suatu perusahaan adalah tergantung pada karyawannya oleh sebab itu perusahaan bisa menggala potensi sumber daya manusia baik dari pemikiran dan fisik (tenaga) dari para karyawan yang bekerja atau mengabdi pada perusahaan tersebut yang sekaligus merupakan jembatan untuk mencapai tujuan perusahaan. 
Untuk mewujudkan tujuan perusahaan tersebut tidaklah mudah, tetapi diperlukan sumber daya manusia yang handal dan profesional, manajemen yang baik dan organisasi yang sehat, dan untuk mendukung hal tersebut salah satu usaha yang dilakukan yaitu dengan cara memotivasi karyawan dalam rangka untuk meningkatkan produktivitas karyawan. Motivasi sangat penting artinya dalam mencapai tujuan organisasi atau sasaran kerja. Karena itu motivasi merupakan modal utama untuk berprestasi. Tetapi harus diakui bahwa tidaklah mudah bagi sebuah perusahaan menumbuhkan motivasi bagi para karyawan. Karena keinginan dan sifat setiap karyawan yang sangat bervariasi serta berubah-ubah, sehingga sangat sulit untuk ditentukan.

Perusahaan dan karyawan merupakan dua hal yang saling membutuhkan satu sama lain tujuan perusahaan akan tercapai jika tujuan individu karyawan tercapai, maka apa yang diberikan oleh perusahaan sangat berpengaruh terhadap motivasi kerja karyawan. Bagi karyawan keberhasilan merupakan aktualisasi potensi sekaligus peluang untuk mamenuhi kebutuhan hidupnya. Sedangkan bagi perusahaan, keberhasilan merupakan serana menuju pertumbuhan dan perkembangan perusahaan. Sebagai seorang karyawan yang memiliki perasaan dan keinginan atas kepentingan individu, maka faktor-faktor yang dapat meningkatkan motivasi kerja perlu diperhatikan. Itulah sebabnya mengapa peran manusia sebagai karyawan sangat besar pengaruhnya sebagai motor penggerak (driving force) dan sebagai agen perubahan (agen of change).

Motivasi dapat dipandang sebagai perubahan energi dalam diri seseorang yang ditandai dengan munculnya feeling, dan didahului dengan tanggapan terhadap adanya tujuan. Jadi, motivasi adalah dorongan dasar yang menggerakkan seseorang atau keinginan untuk mencurahkan segala tenaga karena adanya suatu tujuan. Sikap mental karyawan yang positif terhadap situasi kerja itulah yang memperkuat motivasi kerjanya untuk mencapai kinerja yang maksimal. Tiga unsur yang merupakan kunci dari motivasi yaitu upaya, tujuan organisasi, dan kebutuhan.

Pada dasarnya, tujuan organisasi dapat tercapai bila memperhatikan adanya motivasi yang ada pada karyawannya. dua aspek pendorong timbulnya motivasi yaitu aspek dari dalam (intrinsik) dan aspek dari luar diri (ekstrinsik). Demikian pula karyawan pada PT. Dwie Warna Karya GHOM (Golden Hill Oil Mill) Desa Sei Hanyo Kecamatan Kapuas Hulu Kabupaten Kapuas perusahaan yang bergerak pada bidang produksi pengolahan minyak kelapa sawit dengan karyawan berjumlah sebanyak 107 karyawan. Sebagaimana perusahaan lainnya, perusahaan ini juga berkepentingan terhadap kinerja karyawannya. Sebab dengan kinerja karyawan yang baik atau bahkan meningkat, maka berarti prestasi kerja karyawan juga baik atau meningkat. Berdasarkan observasi awal dari keterangan pemimpin/manajer PT Dwie Warna Karya GHOM (Golden Hill Oil Mill) Desa Sei Hanyo Kecamatan Kapuas Hulu Kabupaten Kapuas melihat secara umum/secara garis besar tidak ada permasalah pokok tentang motivasi kerja karyawan di perusahaan ini, mereka pada dasarnya yang menjadi motivasi mereka dalam bekerja yaitu mencari uang mencari gajih saja. Bilamana permasalahan tentanng motivasi kerja yang lebih spesifik itu ada pada individu karyawan masingmasing.

Dalam rangka meningkatkan kinerja karyawan sebuah organisasi, atasan seperti manajer dan supervisor haruslah memberikan perhatian yang lebih pada level motivasi dari bawahanbawahannya. Para manajer memperhatikan apa keinginan dan kebutuhan karyawannya, kekuatan yang dimiliki bawahannya serta sasaran-sasaran yang ditetapkan dalam rangka memuaskan kebutuhan diri mereka sendiri. Motivasi terdiri dari 2 faktor, yaitu motivasi intrinsik dan motivasi ekstrinsik. Motivasi intrinsik adalah hal-hal yang mendorong berprestasi yang sifatnya intrinsik, yang berarti bersumber dalam diri seseorang seperti. keberhasilan mencapai sesuatu, pengakuan yang diperoleh, sifat pekerjaan yang dilakukan, dan rasa tanggung jawab. Sedangkan yang dimaksud dengan motivasi ekstrinsik atau pemeliharaan adalah faktor-faktor yang sifatnya ekstrinsik yang berarti bersumber dari luar diri yang turut menentukan perilaku seseorang dalam 
kehidupan seseorang seperti kebijakan organisasi, pelaksanaan kebijakan yang telah ditetapkan , hubungan interpersonal, kondisi kerja , sistem upah dan gaji.

Melihat pentingnya pemberian motivasi kerja dalam meningkatkan kinerja karyawan, maka PT. Dwie Warna Karya GHOM (Golden Hill Oil Mill) Desa Sei Hanyo Kecamatan Kapuas Hulu Kabupaten Kapuas seharus memberikan motivasi kerja kepada seluruh karyawan sehingga peningkatan kinerja dapat tercapai. Kinerja karyawan yang baik merupakan suatu langkah untuk menuju tercapainya tujuan organisasi karena kinerja merupakan sarana penentu dalam mencapai tujuan organisasi.

\section{METODE PENELITIAN}

Metode penelitian yang digunakan adalah metode kualitatif. Adapun jenis penelitian yang digunakan dalam penelitian ini adalah Deskriptif. Kehadiran peneliti di lapangan dalam penelitian kualitatif adalah suatu yang mutlak, karena peneliti bertindak sebagai instrumen peneliti sekaligus pengumpul data. Penelitian ini akan dilaksanakan di salah satu perusahaan yang berada di wilayah kabupaten kapuas Kec. Kapuas hulu Desa Sei Hanyo Provinsi Kalimantan Tengah yaitu perusaahan yang bergerak pada bidang produksi pengolahan minyak kelapa sawit PT. Dwie Warna Karya GHOM (Golden Hill Oil Mill) terletak 350 dari ibu kota Kabupaten Kapuas, dan 40 Km dari Kecamatan Kapuas Hulu, Desa Sei Hanyu. Sumber data dalam penelitian ini terbagi menjadai 2 yaitu sebagai berikut: data primer dan data sekunder.

Prosedur pengumpulan data merupakan langkah strategis dalam penelitian karena tujuan utama dalam penelitian ini untuk memperoleh data agar bukti-bukti dan fakta yang diperoleh sebagai data yang objektif, valid serta tidak menyimpang. Dalam penilitian skripsi ini peneliti menggunakan prosedur pengumpulan data sebafai berikut: observasi, wawancara dan dokumentasi.

Teknik analisis data merupakan langkah yang diambil setelah nelakukan pengumpulan data dan disederhanakan dalam bentuk yang mudah dibaca sehingga mampu memecahakan masalah penelitian. Teknik yang digunakan adalah analisis kualaitatif (analisis data dilapangan). Miles dan Hubermen (Sugiyono, 2016:246), mengemukakan bahwa "aktivitas dalam analisis kualitatif dilakukan secara interaktif dan berlangsung terus menerus sampai tuntas, sehingga datanya sudah jenuh". Aktivitas adalam analisis data, yaitu data reducation, data display, dan conclusion drawing/virification.

Dalam penelitian kualitatif, kriteria utama terhadap data hasil penelitian adalah valid, reliable, dan obyektif. Validitas merupakan derajad ketepatan antara yang terjadi pada objek penelitian dengan data yang dpat dilaporkan oleh peneliti. Menurut Sugiyono (2016:270), menyakatakan bahwa "uji keabsahan data dalam penelitian kualitatif meliputi uju, Creadibility (validitas interbal), transferability (validitas eksternal), dependability (reliabilitas), dan comfirmability (obyektivitas). Tahap penelitian adalah seluruh proses dari penelitian tentang hal-hal yang berkaitan dengan objek yang diteliti agar mendapat hasil yang sebaik-baiknya. Adapun tahaptahap pelaksanaan penelitian ini sebagai berikut : tahap pra penelitian, tahap pelaksanaan penelitian, dan tahap pelaporan.

\section{HASIL DAN PEMBAHASAN}

Adapun temuan penelitian setelah diadakan penelitian di PT. Dwie Warna Karya GHOM (Golden Hill Oil Mill) Desa Sei Hanyo Kecamatan Kapuas Hulu Kabupaten Kapuas , peneliti mendeskripsikan hasil analisis dan temuan penelitian sesuai dengan rumusan masalah penelitian peneliti yang berkaitan dengan motivasi kerja karyawan pada PT.Dwie Warna Karya GHOM (Golden Hill Oil Mill) Desa Sei Hanyo Kecamatan Kapuas Hulu Kabupaten Kapuas . Berdasarkan hasil wawancara dengan karyawan PT. Dwie Warna Karya GHOM (Golden Hill Oil Mill) Desa Sei Hanyo Kecamatan Kapuas Hulu Kabupaten Kapuas adapun temuan penelitian yaitu: 


\section{Motivasi Instrinsik}

Karyawan perusahaan bisa dikatakan sudah cukup baik karena sebagian besar karyawan PT. Dwie Warna Karya GHOM (Golden Hill Oil Mill ) Desa Sei Hanyo Kecamatan Kapuas Hulu Kabupaten Kapuas sudah memperoleh keberhasilan dalam mencapai sesuatu dan sebagian besar dari mereka memperoleh pengakuan dari atasan mereka, dan sifat pekerjaan yang dilakukan sudah sesuai dengan standar pekerjaan dan mereka mempunyai rasa tanggung jawab yang baik terhadap pekerjaan yang mereka jalani.

\section{Motivasi Ekstrinsik}

Karyawan perusahaan bisa dikatakan kurang baik dikarenakan jawaban dari masing-masing karyawan banyak yang mengeluh. Yang pertama terhadap kebijkan organisasi perusahaan yang masih tidak jelas dan tidak ditegaskan sewaktu-waktu bisa mengalami perubahan, yang kedua terhadap pelaksanaan kebijkan organisasinya juga tidak jelas karena dari kebijakannya yang tidak tetap selalu berubah-ubah membuat pelaksanaannya pun tidak baik, yang ketiga terhadap hubungan interpersonal tidak ada permasalahan dalam hubungan antar sesame rekan kerja karyawan memiliki hubungan kerja yang baik, yang keempat terhadap kondisi kerja disini karyawan itu sendiri banyak mengeluh terutama terhadap perlengkapan kerja contohnya seperti pemberian APD (alat perlindungan diri) padahal setiap 6 bulan sekali ada anggaran untuk hal itu. Begitu juga terhadap alat-alat penunjang kerja yang sangat masih kurang, dan yang keenam sistem upah dan gaji dalam pelaksanaan penggajian masih tidak tepat waktu dikarenakan pada saat closing dari pihak estate selalu terlambat untuk closing payroll, maka dari itu pihak pabrik juga akan menerima gaji pun terlambat. pihak pabrik tidak bisa melakukan sistem penggajian tersendiri karena alasanya pabrik ini merupakan bawahan atau naugan dari PT. Dwie Warna Karya jadi, sistem penggajiannya harus sama dengan pihak perkebunan.

Berdasarkan wawancara dan pengambilan data yang dilakukan oleh peneliti selama 3 bulan melaksanakan observasi, wawancara, dan dokumentasi yang dimulai pada bulan Mei-Juli pada PT. Dwie Warna Karya GHOM (Golden Hill Oil Mill ) Desa Sei Hanyo Kecamatan Kapuas Hulu Kabupaten Kapuas, dengan melakukan wawancara langsung dengan setiap karyawan di masingmasing unit stasiun bagian pabrik selanjutnya penulis juga melakukan observasi dan dokumentasi untuk melengkapi data yang diperlakukan untuk tahap penelitian selanjutnya.

Sebelum orientasi, sebagai awal peneliti menghubungi untuk meminta pimpinan PT. Dwie Warna Karya GHOM (Golden Hill Oil Mill) Desa Sei Hanyo Kecamatan Kapuas Hulu Kabupaten Kapuas izin melakukan penelitian atau observasi awal. Pimpinan PT. Dwie Warna Karya GHOM (Golden Hill Oil Mill) Desa Sei Hanyo Kecamatan Kapuas Hulu Kabupaten Kapuas menanggapi permintan izin penelitian atau observasi tersebut dengan baik kemudian pimpinan memberikan izin pada saya selaku mahasiswa yang melakukan penelitian PT. Dwie Warna Karya GHOM (Golden Hill Oil Mill ) Desa Sei Hanyo Kecamatan Kapuas Hulu Kabupaten Kapuas untuk melakukan wawancara dan mengarahkan saya untuk bertanya langsung pada sebagian karyawan di masingmasing unit stasiun mengenai data-data yang terkait dengan motivasi kerja karyawan yang diperlukan dalam melakukan sebuah penelitian. Untuk mengetahui motivasi kerja karyawan yang diliat dari motivasi instrinsik dan ekstrinsik pada penelitian PT. Dwie Warna Karya GHOM( Golden Hill Oil Mill ) Desa Sei Hanyo Kecamatan Kapuas Hulu Kabupaten Kapuas .

\section{Pembahasan mengenai Motivasi Instrinsik :}

\section{Keberhasilan Mencapai Sesuatu}

Bekerja merupakan satu-satunya pangkal tolak bagi manusia yang ingin mencari nafkah untuk mencukupi kebutuhannya sehari-hari, bagi dirinya sendiri maupun keluarganya. Di dalam bekerja seseoarang mengalami berbagai situasi dan keadaan, baik bahagia maupun sedih. Sudah selayaknya jika seseorang menginginkan keadaan yang bahagia. Keberhasilan kerja merupakan keadaan yang 
diinginkan oleh semua orang dalam kehidupannya. Keberhasilan kerja untuk tiap-tiap orang tidak sama ukurannya, karena kita tahu bahwa manusia adalah unik satu dengan yang lain berbeda.

Berdasarkan hasil wawancara kepada setiap karyawan di masing-masing unit stasiun bagian pabrik PT. Dwie Warna Karya GHOM (Golden Hill Oil Mill) Desa Sei Hanyo Kecamatan Kapuas Hulu Kabupaten Kapuas bahwa mayoritas narasumber sudah memperoleh pencapaian atau keberhasilan kerjanya namun ada beberapa karyawan yang merasa belum memperoleh pencapaian atau keberhasilan kerja dikarenakan kurangnya dukungan perusahaan dan pengalaman kerjanya belum memadai. Maka dari itu dapat dikatakan bahwa motivasi kerja instrinsik karyawan berupa keberhasilan mencapai sesuatu dapat dikategorikan cukup puas.

\section{Pengakuan Yang Diperoleh}

Berdayakan karyawan dengan memberikan pengakuan atas prestasinya untuk meningkatkan harga diri dan menanamkan motivasi guna bekerja semaksimal mungkin. Kemampuan karayawan untuk mencapai keberhasilan tergantung pada rasa percaya diri sendiri dan hasratnya untuk bekerja baik secara konsisten.

Berdasarkan hasil wawancara kepada setiap karyawan di masing-masing unit stasiun bagian pabrik PT. Dwie Warna Karya (GHOM Golden Hill Oil Mill) Desa Sei Hanyo Kecamatan Kapuas Hulu Kabupaten Kapuas bahwa mayoritas narasumber sudah memperoleh penilaian kerja yang baik oleh atasan tetapi ada juga yang merasa tidak memperoleh penilaian kerja yang baik dari atasan dikarenakan sebagian karyawan berpendapat bahwa pihak perusahaan kurang memberikan tanggung jawab dan perhatian. Sebenarnya pihak perusahaan memberikan Pengakuan hendaknya selalu disesuaikan dengan karayawan yang bersangkutan. Setiap orang mempunyai kebutuhan yang berbeda-beda karena perlu diakui menurut cara yang berbeda pula. Namun demikian, pastikan pengakuan selalu wajar dan jangan pilih kasih. Maka dari itu dapat dikatakan bahwa motivasi kerja instrinsik karyawan berupa pengakuan yang diperoleh dapat dikategorikan cukup puas.

\section{Sifat Pekerjaan Yang Diperoleh}

Sifat pekerjaan adalah pekerjaan yang berpengaruh dalam penetapan formasi, yaitu sifat pekerjaan yang ditinjau dari sudut waktu untuk melaksanakan pekerjaan itu sendiri.

Berdasarkan hasil wawancara kepada setiap karyawan di masing-masing unit stasiun bagian pabrik PT. Dwie Warna Karya GHOM (Golden Hill Oil Mill) Desa Sei Hanyo Kecamatan Kapuas Hulu Kabupaten Kapuas yang membahas tentang sifat pekerjaan dan imblan/upah yang diterima karyawan bahwa mayoritas narasumber dalam sifat pekerjaan dan imblan/upah yang diterima sudah sesuai. Tidak ada keluhan dari setiap karyawan yang sudah di wawancara karena rata-rata dari jawaban mereka sistem upah/imbalan itu mereka dapatkan sesuai dengan mengikuti standar dari UMK. Maka dari itu dapat dikatakan bahwa motivasi kerja instrinsik karyawan berupa sifat pekerjaan yang dilakukan dapat dikategorikan sangat puas.

\section{Rasa Tanggung Jawab}

Dalam hal ini perusahaan bertanggung jawab kepada karyawan mereka yang berkerja pada perusahaan tersebut. Yang diperlukan perusahaan ialah jangan memaksa karyawan sampai batas kemampuan, memperlakukan karyawan dengan baik dan juga memberikan asuransi bagi karyawan yang sakit atau kecelakaan karja karena mereka adalah tanggung jawab perusahaan.

Berdasarkan hasil wawancara kepada setiap karyawan di masing-masing unit stasiun bagian pabrik PT. Dwie Warna Karya GHOM (Golden Hill Oil Mill) Desa Sei Hanyo Kecamatan Kapuas Hulu Kabupaten Kapuas yang membahas tentang tanggung jawab yang diberikan oleh atasan dalam pekerjaan. Bahwa untuk perlakukan kerja atau tanggung jawab yang diberikan oleh pihak perusahaan masih ada sedekit penekanan terhadap karyawan dalam bekerja tetapi dalam peberian tanggung jawab seperti jaminan sosial BPJS ketenagakerjaan dan BPJS kesehatan juga sudah sesuai atau baik. Selain itu tanggung jawab atasan juga sewaktu-waktu mengkoordinasikan 
pekerjaan karyawan. Maka dari itu dapat dikatakan bahwa motivasi kerja instrinsik karyawan berupa rasa tanggung jawab dapat dikategorikan puas .

\section{Pembahasan mengenai Motivasi Ekstrinsik :}

\section{Kebijaksanaan organisasi}

Kebijakan organisasi adalah suatu organisasi, instansi atau lembaga dalam ruang lingkup keamanan jaringan untuk akses pada sistem jaringan tempat tersebut yang dimana pada penelitian ini pada PT. Dwie Warna Karya GHOM (Golden Hill Oil Mill) Desa Sei Hanyo Kecamatan Kapuas Hulu Kabupaten Kapuas.

Berdasarkan hasil wawancara kepada setiap karyawan di masing-masing unit stasiun bagian pabrik PT. Dwie Warna Karya (GHOM Golden Hill Oil Mill) Desa Sei Hanyo Kecamatan Kapuas Hulu Kabupaten Kapuas yang membahas tentang bagaimana organisasi didalam perusahaan. Bahwa masih banyak karyawan yang mengeluh tentang kebijakan organisasi di PT. Dwie Warna Karya GHOM (Golden Hill Oil Mill ) ini sendiri dikarena peraturan yang ditetapkan sewaktuwaktu selalu berubah-ubah dan tidak ada ketegasan dalam peraturan yang sudah diberlakukan. Tetapi ada juga sebagian karyawan menanggapi tentang kebijakan organisasi di PT. Dwie Warna Karya GHOM (Golden Hill Oil Mill) sudah terstruktur dengan baik. Maka dari itu dapat dikatakan bahwa motivasi kerja ekstrinsik karyawan berupa kebijakan organisasi dapat dikategorikan tidak puas.

\section{Pelaksanaan Kebijakan Yang Telah Ditetapkan}

Berdasarkan hasil wawancara kepada setiap karyawan di masing-masing unit stasiun bagian pabrik PT. Dwie Warna Karya GHOM (Golden Hill Oil Mill) Desa Sei Hanyo Kecamatan Kapuas Hulu Kabupaten Kapuas yang membahas tentang bagaimana pelaksanaan kebijkan organisasi yang telah ditetapkan. Dari jawaban narasumber sebagian karyawan mengeluh dikarenakan bagaimana pelaksanaan bisa berjalan dengan lancar sedangkan kebijakannya sewaktu-waktu bisa berubah-ubah dan tidak ada ketegasan dalam peraturan yang sudah diberlakukan misalkan hari ini ditetapkan peraturan A dan besoknya lagi bisa berubah menjadi peraturan B. jadi, kebijakan organisasinya juga kurang jelas. Tetapi ada juga sebagian dari karyawan yang menjawab bahwa pelaksanaan kebijkan organisasinya sudah berjalan dengan baik dan terstruktur oleh manajemen. Maka dari itu dapat dikatakan bahwa motivasi kerja ekstrinsik karyawan berupa pelaksanaan kebijakan yang telah ditetapkan dapat dikategorikan tidak puas.

\section{Hubungan interpersonal}

Hubungan interpersonal atau antar manusia adalah hubungan kemanusian yang harmonis tercipta atas kesadaran dan kesedian melebur keinginan individu demi terpadunya kepentingan bersama yaitu kemajuan perusahaan. Maka manager hendaknya terbuka mendorong partisipasi dan keberadan para karyawan untuk mencampaikan pendapat dan keluhan-keluhannya.

Berdasarkan hasil wawancara kepada setiap karyawan di masing-masing unit stasiun bagian pabrik PT. Dwie Warna Karya GHOM (Golden Hill Oil Mill) Desa Sei Hanyo Kecamatan Kapuas Hulu Kabupaten Kapuas yang membahas tentang apakah memiliki hubungan baik dengan rekan kerja, dan apakah sering berdiskusi dengan rekan keraja bila mengalami kesulitan dalam bekerja. Bahwa tidak ada keluhan dari setiap karyawan yang sudah di wawancara karena rata-raata dari jawaban mereka memiliki hubungan baik sesama rekan kerja karena menurut meraka memiliki hubungan baik dengan rekan kerja itu sangat penting dengan terjalinnya hubungan yang baik, situasi kerja juga akan kondusif dan lebih menyenangkan. Sebagai makhluk sosial, kita diciptakan berdampingan dengan makhluk lainnya, terutama sesama manusia untuk dapat saling berkomunikasi, berinteraksi, saling membangun dan bersinergi. dan juga sering mengadakan diskusi ketika mengalami kesulitan dalam pekerjaan karena dengan berdiskusi permasalahan yang dihadapi bisa dipecahkan secara bersama-sama. Maka dari itu dapat dikatakan bahwa motivasi kerja ekstrinsik karyawan berupa hubungan interpersonal dapat dikategorikan sangat puas. 


\section{Kondisi kerja}

Kondisi kerja merupakan kondisi atau keadaan kerja yang menjadi tempat kerja, yang perlu diperhatikan perusahaan agar karyawan dapat bekerja dengan baik dan nyaman sehingga dibutuhkan fasilitas-fasilitas penunjang kerja. Karena dengan tidak adanya fasilitas kerja maka kegiatan didalam perusahaan tidak akan berjalan dengan baik karena fasilitas kerja sangat menunjang dalam kegiatan didalam suatu perusahaan.

Berdasarkan hasil wawancara kepada setiap karyawan di masing-masing unit stasiun bagian pabrik PT. Dwie Warna Karya GHOM (Golden Hill Oil Mill) Desa Sei Hanyo Kecamatan Kapuas Hulu Kabupaten Kapuas yang membahas tentang apakah nyaman bekerja pada perusahaan PT. Dwei Warna Karya GHOM (Golden Hill Oil Mill ) Desa Sei Hanyo Kecamatan Kapuas Hulu Kabupaten Kapuas dan apakah fasilitas dan perlengkapan kerja sudah menunjang kerja. Bahwa ada karyawan yang menjawab tidak terlalu nyaman alasannya yaitu dalam perlengkapan kerja masih sangat kurang di masing-masing bagian statiun terutama terhadap alat-alat kerja. Tentang fasilitas yang sudah disediakan pihak perusahaan seperti perumahan, air ,listrk dan sebaginya sudah memadai. Maka dari itu dapat dikatakan bahwa motivasi kerja ekstrinsik karyawan berupa kondisi kerja dapat dikategorikan tidak puas.

\section{Sitem upah dan gaji}

Gaji yaitu balasan jasa dalam bentuk uang yang diterima oleh karyawan sebagai konsekuensi dari statusnya sebagai karyawan yang memberikan kontribusi didalam pencapaian tujuan perusahaan.

Berdasarkan hasil wawancara kepada setiap karyawan di masing-masing unit stasiun bagian pabrik PT. Dwie Warna Karya GHOM (Golden Hill Oil Mill) Desa Sei Hanyo Kecamatan Kapuas Hulu Kabupaten Kapuas yang membahas tentang apakah gaji yang diperoleh selalu diterima tepat waktu, dan apakah gaji yang diperoleh sudah sesuai dengan pekerjaan yang di tekuni sekarang pada PT. Dwie Warna Karya GHOM (Golden Hill Oil Mill ) Desa Sei Hanyo Kecamatan Kapuas Hulu Kabupaten Kapuas bahwa dalam penerimaan gaji rata-rata jawaban karyawan masih belum tepat waktu alasannya dikarenakan pada saat closing dari pihak estate selalu terlambat untuk closing payroll, maka dari itu pihak pabrik juga akan menerima gaji pun terlambat. Pihak pabrik tidak bisa melakukan sistem penggajian tersendiri karena alasanya pabrik merupakan bawahan atau naugan dari PT. Dwie Warna Karya jadi, sistem penggajiahannya harus sama dengan pihak perkebunan. Gaji yang diterima oleh masing-masing karyawan sudah sesuai dengan tanggung jawab pekerjaan yang sedang ditekuni sekarang dimasing-masing bagian kerja. Maka dari itu dapat dikatakan bahwa motivasi kerja ekstrinsik karyawan berupa sistem upah dan gaji dapat dikategorikan cukup puas.

\section{KESIMPULAN DAN SARAN}

\section{Kesimpulan}

Berdasarkan uraian serta hasil dan pembahasan yang telah disajikan pada bab-bab sebelumnya maka dapat ditarik kesimpulan hasil penelitian yang didapat oleh penulis tentang motivasi instrink dan ekstrinsik di PT. Dwie Warna Karya GHOM (Golden Hill Oil Mill) Desa Sei Hanyo Kecamatan Kapuas Hulu Kabupaten Kapuas sebagai berikut:

Motivasi instrinsik karyawan perusahaan bisa dikatakan sudah cukup baik karena sebagian besar karyawan PT. Dwie Warna Karya GHOM (Golden Hill Oil Mill) Desa Sei Hanyo Kecamatan Kapuas Hulu Kabupaten Kapuas sudah meperoleh keberhasilan dalam mencapai sesuatu dan sebagian besar dari mereka memperoleh pengakuan dari atasan mereka, dan sifat pekerjaan yang dilakukan sudah sesuai dengan standar pekerjaan dan mereka mempunyai rasa tanggung jawab 
yang baik terhadap pekerjaan yang mereka jalani. Motivasi ekstrinsik karyawan perusahaan bisa dikatakan kurang baik dikarenakan jawaban dari masing-masing narasumber atau karyawan banyak yang mengeluh. Yang pertama terhadap kebijkan organisasi perusahaan yang masih tidak jelas dan tidak tetap sewaktu-waktu bisa mengalami perubahan dan tidak ada ketegasan dalam peraturan yang diberlakukan, yang kedua terhadap pelaksanaan kebijakan organisasinya juga tidak jelas karena dari kebijakannya yang tidak tetap selalu berubah-ubah membuat pelaksanaannya pun tidak baik, yang ketiga terhadap hubungan interpersonal tidak ada permaslahan dalam hubungan antar sesame rekan kerja karyawan memiliki hubungan kerja yang baik, yang keempat terhadap kondisi kerja disini narasumber atau karyawan itu sendiri banyak mengeluh terutama terhadap perlengkapan kerja contohnya seperti pemberian APD (alat perlindungan diri) padahal setiap 6 bulan sekali ada anggaran untuk hal itu. Begitu juga terhadap alat-alat penunjang kerja yang sangat masih kurang, dan yang keenam sistem upah dan gaji dalam pelaksanaan penggajian masih tidak tepat waktu dikarenakan pada saat closing dari pihak estate selalu terlambat untuk closing payroll, maka dari itu pihak pabrik juga akan menerima gaji pun terlambat. Pihak pabrik tidak bisa melakukan sistem penggajian tersendiri karena alasanya pabrik ini merupakan bawahan atau naungan dari PT. Dwie Warna Karya jadi, sistem penggajiannya harus sama dengan pihak perkebunan.

\section{Saran}

Dari kesimpulan yang diperoleh dalam penelitian ini, maka penulis memberikan saran kepada pihak perusahaan sebagai bekitut:

1. Hendaknya dalam kebijakan oraganisasi maupun pelaksanaannya perusahaan memperbaik sistem kerja.

2. Hendaknya perusahaan memperbaiki fasilitas atau penunjang kerja di perusahaan agar tidak banyak karyawan mengeluh.

3. Hendaknya perusahaan melengkapi perlengkapan kerja untuk mendukung produktivitas kerja karyawan.

4. Hendaknya perusahaan setiap 6 bulan sekali melakukan pemberian terhadap APD (alat perlindungan diri) karena setiap 6 bulan sekali ada anggran untuk hal itu.

\section{DAFTAR PUSTAKA}

Arep, Ishak. Tanjung, Hendri. 2003. Manajemen Motivasi. Cetakan kedua. Jakarta: PT. Grasindo. Cetakan Keenam, Penerbit: PT. Bumi Aksara.

Gibson, James, L., 2011, Organisasi, Perilaku, Struktur dan Proses, Edisi ke-5. Cetakan ke-3. Jakarta: Penerbit Erlangga

Handoko, T. Hani, 2004, Manajemen Personalia Dan Sumber Daya Manusia, edisi kedua. Cetakan Keempat Belas, Penerbit BPFE-UGH, Yogyakarta

Hasibuan, Malayu S.P. 2008. Manajemen Sumber Daya Manusia. Jakarta : Penerbit Bumi Aksara.

Hasibuan, Malayu S.P. 2012. Organisasi dan Motivasi. Cetakan ke-2, Jakarta: Bumi Aksara

Herman, Sofyandi. 2008. Manajemen Sumber Daya Manusia. Yogyakarta : Graha Ilmu.

Jones, Garett R. 1997. Organizational Theory: Text and Cases. Addison-Wesley Publishing Company.

Luthans, Fred. 2011. Perilaku Organisasi. Cetakan Keempat. Yogyakarta: Penerbit Andi Offset

Mangkunegara Anwar Prabu, 2013, Manajemen Sumber Daya Manusia Perusahaan, Remaja Rosdakarya, Bandung 
Pangabean, S. Mutiara, 2004. Manajemen Sumber Daya Manusia, Penerbit Ghalia Indonesia, Bogor.

Sugiyono. 2016. Metode Penelitian Kuantatif, Kualitatif, dan R\&D, Bandung Alfhabet

Siagian, Sondang P, 2014. Sumber Daya Manjemen Manusia. Jakarta: Bumi aksara

Nur Armiasih. 2013. Analisis motivasi kerja karyawan kud mutiara rakyat di kuala mempawah timur. Skripsi. Universitas tanjungpura Pontianak. Di unduh pada tanggal 4 April 2019, dari jurnal.untan.ac.id/index.php/jpdpb/article/view/4004

Rika Suwito. 2013. Analisis Motivasi Kerja Karyawan Pada PT. Bank Sumut KCP Marela Medan. Skripsi. Politeknik LP3I Medan. Di unduh pada tanggaln 4 april 2019, dari https://ejurnal.plm.ac.id/index.php/BIS-A/article/view/111/93

Astuti. 2017. Analisis Motivasi Kerja Karyawan Dalam Upaya Meningkatkan Produktivitas Kerja Karyawan Studi Kasus Bagian Assembling Perusahaan Metal Button. Skripsi. Universitas pasundan bandung. Di unduh pada tanggal 4 April 2019. Dari epository.unpas.ac.id/29352/1/Jurnal\%20upload\%20150917.pdf 